\title{
ISLAMIC FINANCIAL LITERACY IN MUSLIM MAJORITY COUNTRY
}

\author{
Irfan Syauqi Beik ${ }^{1}$ \\ Laily Dwi Arsyianti \\ ${ }^{1,2}$ IPB University \\ Email: irfan_beik@apps.ipb.ac.id, arsyianti@apps.ipb.ac.id
}

\begin{abstract}
Various researches have been carried out by the most populous Muslims country in the world to identify the level of literacy towards Islamic economics and finance. The results show that the literacy levels are still far below the target. This paper attempts to identify the programs that have been organized to increase the literacy level, the potential of human resources to lift up the level, as well as the research and development that have been and potential to be carried out in order to achieve much more level of literacy as targeted by the authority.
\end{abstract}

Keywords: Indonesia, Islamic financial literacy, Muslim majority country, Islamic economics and finance education

\section{INTRODUCTION}

Human resources is the potential that needs to be developed, both in terms of literacy, the quality of education, and the resulting output. Under normal conditions, before the COVID-19 pandemic occurs programs to improve literacy and Islamic economic and financial education have been carried out starting from basic education in school to practitioners in the banking and non-bank industries.

The education program is also integrated with the real sector, as practiced by Bank Indonesia (BI) on the development of the Islamic education in pesantren with the rural economic development. Pesantren is an education institution with its core basis is an Islamic religious teaching which are mostly located in the rural and suburban area. This practical teaching can be seen in the most populous Muslim country in the world and implemented in almost crossover Indonesia which has more than 17 thousand islands.

The Ministry of Finance of the Republic of Indonesia and the Financial Services Authority (in Indonesian language it is abbreviated OJK) also have been organizing promotional events to introduce investment products such as sukuk and sukuk savings to universities community through the "Sukuk Goes to Campus" program. Likewise, institutions related to the social sector such as the Indonesian Waqf Board (BWI) have also been organizing such program. For example, an event to socialize waqf through "Waqf Goes to Campus".

Such various programs are able to captivate participants who are on target. However, the achievement of Islamic finance industry is still far from its target. The 5\% target of Islamic banking asset which was expected to be achieved in 2008, was realized in 2016. This paper will discuss literacy programs, improvement of human resources and the research and development programs which are related with Islamic economics and finance, as well as the current situation that occurs during the implementation of large-scale social restrictions.

The presentation of this paper is based on literature studies according to various national authorities related with Islamic economics and finance in the most populous Muslims country in the world, Indonesia. Hence, this paper uses literature studies approach to explore what have been studied to the extent of financial literacy in Indonesia. This study attempts to generate possible outcomes after various surveys have been done by related stakeholders. 


\section{RESEARCH ON ISLAMIC FINANCE LITERACY BY AUTHORITIES}

The Financial Services Authority (OJK) conducted literacy surveys focusing on financial products in general, including those Islamic sharia-compliant. The aims of the conducted survey in 2019 by the OJK were including to identify the latest level of financial literacy, to formulate effective policies to increase literacy, to measure the effectiveness of financial education and literacy programs, and to develop strategies to fulfil financial products and services according to consumer needs.

A total of 12798 respondents were selected by semi random sampling with restricted quota from 34 provinces throughout Indonesia in the age range of 17-79 years, with a background regardless of their religion. Thus, the respondents were not only Muslims, but also included non-Muslims. Even though Muslims are majority in this country, it is expected that Islamic finance industry can also target nonMuslims since the philosophy of this system is not only for Muslims but rather for all human beings.

The survey results show that for Islamic finance, there was a slight increase in the literacy index from the 2016 survey, from $8.11 \%$ to $8.93 \%$. This shows that in 3 years, the increase in literacy was only $0.82 \%$, or around $0.27 \%$ per year. This result on index alone has been giving us a signal to pace up our efforts in educating and promoting Islamic economics and finance.

In the 2016 survey, the highest literacy of Islamic financial products was towards Islamic banking products, followed by Islamic insurance products, then pawnshops. Surprisingly, Islamic capital market instruments were not even in the top three of the literacy. The most well literate populations were in the provinces of East Java, Aceh, DKI Jakarta, North Maluku and Jambi. The literacy rate of Islamic financial products in 2016 was still very far from the total of national financial literacy which reached $29.66 \%$.

Another authority institution, Bank Indonesia, released the results of their survey on Islamic economic literacy levels of the Indonesian population in March 2020. BI examines knowledge of Islamic economic terms, knowledge of Islamic social financial institutions, skills, attitudes towards the future, Islamic financial management behaviour, and knowledge of halal products and services. Allgood \& Walstad (2016) found that perceived financial literacy can be more effective in influencing financial behaviour rather than the actual financial literacy. Therefore, all aspects that might lead to the increase in tendency of Islamic economics and finance behaviour should be included.

The respondents consisted of 3182 Muslims aged 17-65 years and spread across 13 provinces. Through cluster and biplot analysis and structural equation modelling (SEM), the survey results show that $16.3 \%$ of the surveyed Indonesia's population has a good literacy rate. Well literate is defined as having knowledge of at least $75 \%$ of every aspect of literacy. $16.3 \%$ was dominantly generated from the contribution of aspects related to Islamic social financial institutions as well as the aspect of attitude towards the future.

The literacy aspect of Islamic social financial institutions consisted of a knowledge component of Islamic social fund management institutions. These institutions included zakat institutions (both organizing zakat fitrah and maal), waqf institutions, charity institutions, Masjid and pesantren. Meanwhile, attitudes toward the future consisted of components that were carried out in daily basis, such as focusing on the short term or the daily routines, or focusing on the long term or the future.

Overall, the aspects of Islamic economics knowledge contributed the most to the level of Islamic literacy, according to this survey. This aspect comprised of knowledge or understanding of Isalmic economic values or its belief which included usury, profit sharing, maysir or speculation, hoarding, zakat (both fitrah and maal), as well as knowledge about voluntary charity (infaq). In addition to aspects of Islamic social financial institutions, the third largest contribution was contributed from the numerical or calculation aspects of Islamic economics. This aspect comprised of the ability to perform financial calculations by observing Islamic principles such as profit-sharing, calculating zakat and calculating financial options for buying items that are Islamic sharia-compliant.

As an authority institution in social finance, National Board of Zakat (abbreviated BAZNAS), in collaboration with Ministry of Religious Affairs, has released their research on zakat literacy. The survey covered 32 provinces with a total of 3200 respondents from various backgrounds of affiliations. They were 
students, public servants, white collar workers, entrepreneurs, and other occupations which each of them represented one fifth of respondents, almost equally.

The zakat literacy index survey show that the surveyed Indonesia's population has a moderate level of literacy, with a score of 66.78. Basic knowledge of zakat contributed the highest score among the dimensions. Meanwhile the advanced knowledge got the lowest score. The highest score was about the basic concept of zakat, followed by the concept of asnaf. In the meantime, the lowest score was a literacy about zakat regulation. Therefore, it is obvious that Indonesia society has not yet familiar with zakat regulations where there are stated that formal zakat institutions have been appointed by Indonesia regulations. This leads us to give more effort to introduce formal zakat institutions to the society. According to the survey, most of them were still paying zakat informally via masjid.

Apparently, Bali, that is a home for majority non-Muslims, had the highest score of the basic knowledge of zakat among other provinces. Meanwhile, for the advanced knowledge of zakat, Gorontalo had the highest score. Overall, the Province of Riau Islands got the highest score, followed by Gorontalo. Among respondents, almost half of them acknowledged that they have not yet paid zakat. Mostly, they got their information about zakat from their ustadz or local 'ulama, followed by office/university. In conclusion, so far, the effective media of zakat education are through Islamic teaching by local 'ulama or formal announcement in the office/university. In this case, the financial advisor that can be recruited as suggested by Calcagno \& Monticone (2015) that independent financial advisor can be more effective in delivering the financial literacy. More than half of them paid zakat during Ramadan rather than other time of preference.

The National Sharia Financial Economics Committee (KNEKS) has also conducted a literacy survey and released the results in 2019 with a focus on financial management. The KNEKS research survey used the focus group discussion (FGD) method as well as questionnaires distributed to 335 respondents by purposive sampling, and interviews.

The results of the FGD recommended the proposed literacy materials which are suitable for the sequential phases of human life from birth to above 56 years. For the 0-6-year phase, media literacy and Islamic financial education included manual books for parents, 1-3-minute animation videos, flash cards, storytelling with picture books, manuals and simple literacy books for caregivers. This media does not differ much for the 7-15-year phase, namely 1-3-minute animation videos, comic books, picture books, exercise books with the concept of appreciation, and role play. As studied by Worthington (2016), Australia had financial literacy curriculum from Kindergarten level to Year 12. Indonesia can also start instilling the Islamic economics and finance curriculum from the early level of formal education.

The appropriate media of education for teenagers 16-18 years, were videos of success stories of financial discipline, financial preparation books for new families, training, workshops. Growing older into university age 19-23 years, media literacy and education were suggested to be more mature in reading materials such as family financial books, manuals for husband and wife starting the concept of living, books about separated assets, shared assets, debt and investment management books, zakat and inheritance, family financial planning book. Training and workshops were needed to be provided for them in understanding the preparation and entering the age of marriage.

Entering the 24-55-year phase, Islamic financial education and literacy media were not different from the media in the preparatory phase of entering a household, such as family financial books, debt and investment management, zakat and inheritance, retirement preparation, books and economic training, business and social. In addition, in this phase it was also necessary to start training and workshops to gain a deep understanding. Meanwhile, entering the age leading up to retirement, which is 56 years and over, the literacy and education media were also adjusted such as mentoring books after retirement, accounts receivable debt books, inheritance books. Besides needing to be given assistance after retirement, training and workshops.

Questionnaire survey results show that for the aspects of wealth creation, wealth generating, wealth protection, wealth purification, and wealth distribution, the families earned more than 4 million rupiahs had a tendency of higher levels of economic and Islamic finance literacy than households earned under 4 million 
rupiahs in each categories of children and adolescents as well as adults and old age in DKI Jakarta, BangkaBelitung and South Kalimantan. Bangka-Belitung received the highest literacy rate compared to the other two provinces, which reached $32.6 \%$. The aspect of wealth creation had the biggest contribution to a good literacy level. The largest component was achieved for the themes that were closely related to daily economic and financial activities such as obtaining halal income, protecting assets for children, saving behavior and planning for the future, as well as spending on donations, charity and zakat. Themes such as the use of Islamic insurance for wealth protection, payment of zakat to formal zakat institutions, waqf instruments, and calculation and distribution of inheritance were still poorly understood by the selected respondents.

\section{Prevailed Literacy Activities}

The four studies of OJK, BI, BAZNAS and KNEKS have emphasized the importance of education and literacy program to the public and stakeholders in particular. In normal situations, education and literacy are carried out directly to accessible places such as schools, universities, and in collaboration with scientific forums such as the Association of Islamic Economics Experts (IAEI). Activities such as "Waqf Goes to Campus", "Sukuk Goes to Campus", and socialization by amil institutions such as "Amil Goes to Campus" become effective and always be an interesting educational media because usually they brought out various expert well-known speakers in their respective fields and offered door prizes which attracted the attention of the participants and booth visitors who were presented during the event.

In addition, Islamic economic and financial education and literacy events such as the Indonesia Sharia Economic Festival (ISEF) have been held every year since 2014 by Bank Indonesia, the Sharia Economic and Financial Research Forum (abbreviated FREKS) organized by OJK, and The Annual Islamic Finance Conference (AIFC) by the Ministry of Finance of the Republic of Indonesia is the largest educational event which were some of many efforts to expand the target of education and literacy to the public, especially practitioners and academicians.

Islamic economic and financial literacy and education also targets exceptional human resources (HR) that can be immersed at productive age. Among these programs was the strengthening and standardizing the curriculum in study programs related to Islamic economics and finance. Based on data from the National Higher Education Accreditation Board (abbreviated as BAN-PT) in 2018, there were 10 A-accredited Islamic Economics study programs. B-accredited study programs were in total 99 study programs and Caccredited were 10 study programs (MEKSI 2019).

The potential of human resources in Indonesia has a fairly good quality. The efforts to optimize HR are still far behind that of other countries in the world. According to data from the 2017 Global Competitiveness Index (GCI), on the fifth pillar, one of the determinants of the quality of human resources was higher education and training. Indonesia is only ranked 63rd out of 138 countries (World Economic Forum, 2017). This showed us that various parties and stakeholders should give full and better support, especially from regulators, practitioners and academicians.

Research and development in Indonesia are regulated in Act No. 18 of 2002 concerning the National System of Research on Technology and Science. The government stated in the Act, a research has the aim "to strengthen the carrying capacity of science and technology for the purposes of accelerating the achievement of the country's goals, as well as increasing competitiveness and independence in fighting for the interests of the state in international relations." However, despite the support of the Act, Indonesia's budget in research and development was still relatively small. Based on World Bank data (2020), spending on research and development on GDP in 2018 was only 0.27, compared to India 0.60 (2018), Malaysia 1.44 (2016), Singapore 2.17 (2016), Japan 3.21 (2017), and world average 2.22 (2017). 


\section{LITERACY, HUMAN RESOURCES, RESEARCH AND DEVELOPMENT FAST FORWARD}

Financial education needs to embrace all stakeholders including public and private schools where the formal education has started. As suggested by Arsyianti, Kassim, \& Adeyemi (2018) who found that Islamic financial education is encouraged to be introduced early in school with the support of financial institutions as practitioners. During conventional situation, meeting face-to-face interactively with practitioners can be done either by visiting the institutions or the practitioners themselves visiting the schools.

The process of Islamic economics and financial education and literacy became a real challenge even before the COVID-19 pandemic stroked many countries in the world. It was during this time that various activities declined marked by health, economic and social impacts. This situation limits interactive face-to-face motion in the public domain, so activities involving a mass of more than 25 people must be eliminated. The intensity of the implementation of Islamic economics and finance educational and literacy programs must find alternatives and change the strategy. Whenever the planned programs prior to the enactment of this limitation were crucial and significant in literacy that requires public meetings, then the program should not be canceled, but the delivery method must be replaced. The delivery strategy can be done by several methods, particularly by using online media or in Indonesian terms referred to "in the network" (abbreviated by "daring") as a substitute for face-to-face ("off the network", or abbreviated by "luring") media. We also acknowledge the activities as webinar.

Besides being a challenge itself, the COVID-19 pandemic period can also be a huge opportunity. The online media that are utilized actually set aside the travel time gap from place A to place B, so that it is utilized to carry out online meetings with more frequent. The Association of Islamic Economics Experts (IAEI), Bank Indonesia (BI), the National Board of Zakat (BAZNAS), KNEKS, and various institutions related to Islamic economics and finance were widely using webinars. Moreover, some of the webinars were held in series.

Various international conferences and summer courses such as the Islamic Economics Winter Course are also still organized through online. This method is likely to continue throughout the post COVID-19. Lectures and researches are also carried out with a variety of methods utilizing available technologies. Some use video conferencing media such as Zoom, Microsoft Team, Google Meet, Cisco Webex, and the like or communication via email, chat, voice call, and video calls such as WhatsApp, LINE, and the like. Kuntze, Wu, Wooldridge, \& Whang (2019); Lee (2019) and Lusardi, Samek, Kapteyn, Glinert, Hung, \& Heinberg (2017) found that video and visual interventions including website information, online calculator and external links happened to be the most effective way to increase financial literacy. Therefore, this method can be maintained even after the current situation have relieved and also can be improved for better achievement.

\section{CONCLUSIONS}

Literacy, human resources, research and development of Islamic economics and finance in Indonesia relatively affected mainly by perceived stance and delivery methods. The literacy level of Islamic economics and finance in related fields mostly are still below the target. Researches on literacy have been done as efforts to increase the understanding of Islamic economics and finance and eventually to achieve the designated target of market share in national as well as international level.

As for media of delivery, current situation has brought the method that originally was face to face, was changed to online. This situation is considered as a challenge as well as a huge opportunity for broader coverage of education program. The target can also be broadening to gather participants from various countries around the world without major obstacles, namely the constraints of cost and time, which are encountered previously.

Hopefully through improved literacy program, skilled human resources, as well as widen research and development programs can reach the target of above 25\%, as targeted by Bank Indonesia. Particularly, with the current condition when the use of technology is carried out massively with increasing frequency, 
it is expected that the level of Islamic economics and finance literacy can be increased or even exceed the target.

Parties such as Bank Indonesia, OJK, and related ministries as regulators are expected to be able to accelerate this literacy index. Likewise, practitioners such as amil institutions, waqf institutions, Islamic banks, Islamic rural banks, and Islamic non-bank institutions are also expected to support the increase in the literacy index. Moreover, academicians are expected to be able to create more qualified and skilled human resources who are recognized nationally and internationally, as well as to continue to disseminate researches and ideas for Islamic economics and finance development.

\section{REFERENCES}

Allgood, S., \& Walstad, W. B. (2016). The effects of perceived and actual financial literacy on financial behaviors. Economic inquiry, 54(1), 675-697.

Arsyianti, L. D., Kassim, S., \& Adeyemi, A. A. (2018). Enhancing Financial Education: Debt-Taking and Charity-Giving Context in Indonesia. Li Falah: Jurnal Studi Ekonomi dan Bisnis Islam, 3(2), 32-49.

Association of Islamic Economics Experts (IAEI). (2020). International Webinar Series material. Downloaded from http://www.iaei-pusat.org/news/materi-ekonomi-islam/materi-internationalislamic-webinar-series-3?language $=\mathrm{id}$

Bank Indonesia. (2017). Blueprint for Sharia Economic and Financial Development.

Bank Indonesia. (March 2020). Islamic Financial Literacy Index.

Calcagno, R., \& Monticone, C. (2015). Financial literacy and the demand for financial advice. Journal of Banking \& Finance, 50, 363-380.

Centre of Strategic Studies, National Board of Zakat. (2020). Report of Survey on Zakat Literacy Index.

Financial Services Authority. (2016). 2016 National Literacy and Financial Inclusion Survey.

Kuntze, R., Wu, C. K., Wooldridge, B. R., \& Whang, Y. O. (2019). Improving financial literacy in college of business students: modernizing delivery tools. International Journal of Bank Marketing.

Lee, H. W. (2019). Applying Online Educational Technology to Foster Financial Literacy: FinancialInstitution Leaders' Insights. The Qualitative Report, 24(10), 2625-2654.

Lusardi, A., Samek, A., Kapteyn, A., Glinert, L., Hung, A., \& Heinberg, A. (2017). Visual tools and narratives: New ways to improve financial literacy. Journal of Pension Economics \& Finance, 16(3), 297-323.

National Islamic Economics and Finance Committee. (2019). National Strategy: Development of Educational Materials for Increasing Sharia Economic and Financial Literacy in Indonesia.

National Islamic Economics and Finance Committee. (2019). Indonesian Sharia Economics Master Plan 2019-2024.

World Economic Forum. (2017). Executive Opinion Survey, The Global Competitiveness Index in Detail: Indonesia. Downloaded from http://reports.weforum.org/pdf/gci-20162017/WEF_GCI_2016_2017_Profile_IDN.pdf

World Bank. (2020). Research and development expenditure (\% of GDP), UNESCO Institute for Statistics. Downloaded from https://data.worldbank.org/indicator/GB.XPD.RSDV.GD.ZS?most_recent_value_desc=false

Worthington, A. C. (2016). Financial literacy and financial literacy programmes in Australia. In Financial Literacy and the Limits of Financial Decision-Making (pp. 281-301). Palgrave Macmillan, Cham. 